
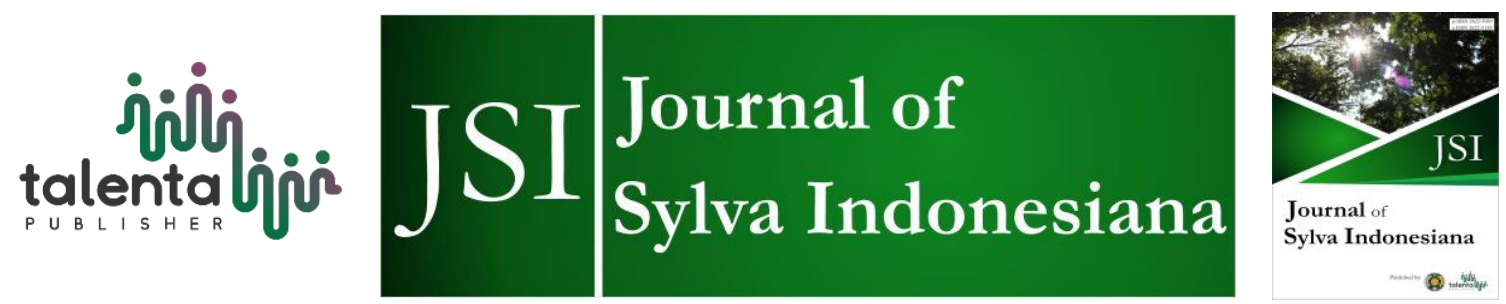

\title{
Analysis The Degree of Community Participation Possibility on Restoration Planning for Lowland Forest Landscape of Lepan Watershed - Langkat District
}

\author{
Nurhayani Hasibuan', Samsuri ${ }^{2}$, Alfan Gunawan Ahmad ${ }^{3}$ \\ ${ }^{1}$ Faculty of Forestry, Universitas Sumatera Utara, Padang Bulan, Medan, 20155, Indonesia
}

\begin{abstract}
Watershed performance can become one of forest condition indicators. Lepan watershed belongs to main priority category in North Sumatra encompassed the forest landscape has a poor condition. It has to be restored for getting the better forest landscape. This activity needs community support and proper plant species for restoring the forest. Therefore, the research is important to determine the degree of community participation possibility in the planning of restoration activities that will be done in Lepan watershed and to find suitable plant species. This research used the descriptive statistical analysis method. The result showed that the degree of community participation possibility on forest landscape restoration activity was high. The selection of the suitability of the plant species used was determined from sum of the proportion of weight based on community perception and the analysis of natural forest vegetation were meranti (Shorea sp), bayur (Pterosperium javanicum), karet (Hevea brasilliensis), durian (Durio zibethinus), benoang (Octomeles sumatrana), matoa (Pometia pinnata), marak (Macaranga indica), jengkol (Pithecellobum jiringa), pulai (Alstonia scholaris), dan meranti batu (Shorea parvifolia).
\end{abstract}

Keyword: Community Participation, Forest Landscape, Restoration, Suitability of Plant Species

Received 4 April 2019 | Revised 10 July 2019 | Accepted 15 August 2019

\section{Introduction}

One hundred years ago Indonesia had abundant forests with trees covered 80 to 95 percent of the total land area. Total forest cover was estimated at around 170 million ha. Currently forest cover is around 98 million hectares, and at least half of the area is believed to has been degraded due to human activities. The degree of deforestation is increasing and Indonesia lost about 17 percent of its forest in the 1985 and 1997 periods. On average, Indonesia lost about one million hectares of forest each year in the 1980s and around 1.7 million ha per year in the 1990s. Since 1996, deforestation seemed to have increased again to around 2 million ha per year. At this level, it seems that all Indonesia's lowland forests that are rich in biodiversity and various timber sources will disappear in the coming

\footnotetext{
*Corresponding author at: Faculty of Forestry, Universitas Sumatera Utara, Padang Bulan, Medan, 20155, Indonesia E-mail address: gsamsuri@gmail.com
} 
decades (Holmes, 2000 cited in [1]). The proper and enough forest cover can support watershed performance. Unfortunately, many watersheds have degraded forest cover and deforestation.

North Sumatra Province, especially Langkat Regency, has several watersheds, one of which is the Lepan watershed. Lepan watershed is categorized into the $1^{\text {st }}$ priority watershed in North Sumatra. This means that it has high management priorities due to its critical or unhealthy biophysical and socio-economic conditions and problems. Research [2] revealed that forest land cover in 2015 was $28.1 \%$ of the total area, less than minimum standards set by the government in Law No.41 of 1999 (30\% of the total watershed area). It indicates that Lepan watershed was not in good condition.

Lepan watershed condition can be improved by restoring forest landscapes as close to previous natural conditions as possible. However, in order to successfully restore the landscape, we need support from community in and around the forest such as their participation from planning to evaluate the restoration. The success of restoration also determined by plant type selection, pioneer types or income-source plants. It is important to know community participation degree and suitable plant type because both are significant factors to determine the success of forest landscape restoration [3]. This research aimed to obtain the degree of community participation possibility in the Lepan watershed in Langkat Regency in forest landscape restoration activities and to discover the suitable type of plant for forest landscape restoration activities in the Lepan watershed in Langkat Regency.

\section{Materials and Methods}

\subsection{Tools and Materials}

The tools and materials used in this study were GPS, writing instruments, cameras, and questionnaires.

\subsection{Methods}

The data collection method used in this study was a semi-structured interview and survey. Semistructured interviews (conversations) involve the individuals or groups for a purpose and carried out using the question guide list. The respondents were given open questions, which answers were not yes or no.

Respondents were selected by purposive sampling method: the technique of determining samples with certain considerations. Samples were respondents who had work or activities and resided in the Lepan watershed in Langkat district.

The research used primary and secondary data. Primary data obtained by field observation included field documentation, field marking, and respondent responses from the questionnaires. Secondary data was supporting data obtained indirectly from previous studies or agencies providing the related data. 


\subsection{Data Analysis}

This study used descriptive statistical analysis studies. Data processing results of questionnaires were carried out using a rating scale. The rating scale is a statement followed by columns indicating degrees, for example was from strongly agree to strongly disagree. This is so that the respondent can provide an assessment according to their criteria based on the choices available. Each respondent's choice of answers was given a score according to the scale of the answer choices available. Each answer A through $\mathrm{E}$ had a degree starting from the most positive and given the highest value as shown in Table 1 and Table 2.

Table 1 Interval rating scale with three options of answers

\begin{tabular}{cccl}
\hline Options & Score & $\begin{array}{c}\text { Interval Rating } \\
\text { Scale }\end{array}$ & \multicolumn{1}{c}{ Category } \\
\hline A & 3 & $201-300$ & $\begin{array}{l}\text { Acknowledge/has } \\
\text { joined/join }\end{array}$ \\
B & 2 & $101-200$ & Doubtful/doubtful/doubtful \\
C & 1 & $0-100$ & Not knowing/never/not join \\
\hline
\end{tabular}

Table 2 Interval rating scale with five options of answers

\begin{tabular}{cccl}
\hline Option & Score & $\begin{array}{c}\text { Interval } \\
\text { Rating } \\
\text { Scale }\end{array}$ & \multicolumn{1}{c}{ Statement } \\
\hline A & 5 & $401-500$ & Strongly agree/very good \\
B & 4 & $301-400$ & Agree/good \\
C & 3 & $201-300$ & Doubtful/unchanged \\
D & 2 & $101-200$ & Disagree/damaged \\
E & 1 & $0-100$ & Strongly disagree/very damaged \\
\hline
\end{tabular}

The degree of community participation possibility in planning restoration activities in Lepan watershed in Langkat Regency was measured using the formula (Kadir, 2007) which modified by [4]:

$$
C P=\frac{\sum_{i, j}^{n} x_{i j}}{A V} x 100 \%
$$

Note :

$\mathrm{CP}=$ community participation measurement

$\mathrm{Xij}=$ the value number of "yes" answer on the ' $\mathrm{i}$ ' question and the ' $\mathrm{j}$ ' respondent

$\mathrm{AV}=$ the actual or supposed value of the respondent's answer

The CP then valued using the category approach developed by (Babbie 1991 cited in [4]) which had been modified as follows:

$\mathrm{CP}$ value $>66.68 \%$

: High participation 
CP value $33.34 \%-66.67 \%$ : Moderate participation

$\mathrm{CP}$ value $<33.33 \% \quad$ : Low participation

The assessment used to find out the types of plants used in restoration planning activities was assessed based on two criteria. The assessment and calculation of tree species that were suitable for restoration activities were a classification modification according to [5]. Type of plants according to the community's opinions and natural forest vegetation analysis obtained from secondary data were used as assessment criteria.

In principle, the determination of tree species is expected to be the same as the tree species found in natural forest ecosystems near the restoration area. However, the restoration implementation had to prioritize the key types for the formation of ecosystems, nests, and animal feed. Vegetated landscapes that were recommended were at least $30 \%$ of the total natural forest ecosystem close to the restoration area [6]. The values on each criterion were presented as follow:

$\mathrm{B}_{1} \quad$ Type of plants according to the community's opinion $40 \%$

$\mathrm{B}_{2}$ Type of plants according to natural forest vegetation analysis $60 \%$

$\mathrm{B}_{1}+\mathrm{B}_{2}=100 \%$

Suitable type of plants $=\left[\left(\mathrm{B}_{1} \times \mathrm{K}_{1}\right)+\left(\mathrm{B}_{2} \times \mathrm{K}_{2}\right)\right]$

Note :

$B_{1}, B_{2}$ : the value of each type of selection criteria

$\mathrm{K}_{1}, \mathrm{~K}_{2}$ : score of each plant type

\section{Results and Discussion}

\subsection{Community Characteristics}

Community characteristics are things that indirectly influence public perceptions of restoration activities on forest landscapes. The characteristics used in this study were the lengths of stay, education, employment, and community income. The number of respondents chosen was 100 people taken from four villages selected as the villages where the research was located in the Lepan watershed in Langkat Regency.

\section{A. Length of Stay}

Table 3 shows that the respondents have lived in the area for 6 to 77 years. The lengths of stay of the respondents were divided into eight categories, starting from 6 years to 77 years. The average lengths of stay were 27 years. 
Table 3 The characteristic of the community in Lepan watershed based on lengths of stay

\begin{tabular}{cccc}
\hline No & $\begin{array}{c}\text { Lengths of stay } \\
\text { (Years) }\end{array}$ & $\begin{array}{c}\text { Number } \\
\text { (person) }\end{array}$ & Percentage (\%) \\
\hline 1 & $6-14$ & 8 & 8 \\
2 & $15-23$ & 38 & 38 \\
3 & $24-32$ & 30 & 30 \\
4 & $33-41$ & 8 & 8 \\
5 & $42-50$ & 11 & 11 \\
6 & $51-59$ & 3 & 3 \\
7 & $60-68$ & 1 & 1 \\
8 & $69-77$ & 1 & 1 \\
\hline
\end{tabular}

\section{B. Education}

Data presented in Table 4 indicates that 3\% of respondents were uneducated and $97 \%$ educated in the range of elementary school to a diploma. In general, elementary school level was dominating with a percentage of $49 \%$. Low education level will be an obstacle in transferring information and technology to the public.

Table 4 The characteristic of the community in Lepan watershed based on education

\begin{tabular}{llcc}
\hline No & \multicolumn{1}{c}{ Education } & $\begin{array}{c}\text { Number } \\
\text { (person) }\end{array}$ & $\begin{array}{c}\text { Percentage } \\
(\%)\end{array}$ \\
\hline 1 & Uneducated & 3 & 3 \\
2 & Elementary School & 49 & 49 \\
3 & Middle School & 16 & 16 \\
4 & High School & 31 & 31 \\
5 & Diploma & 1 & 1 \\
\hline
\end{tabular}

\section{Occupation}

As the listed data in Table 5, the dominated occupation of the community in the study area was farmer, laborer, and housewife. These occupations were related and able to support of forest ecosystem restoration.

Table 5 The characteristic of the community in Lepan watershed based on occupation

\begin{tabular}{llcc}
\hline No & Occupation & $\begin{array}{c}\text { Number } \\
\text { (person) }\end{array}$ & Percentage (\%) \\
\hline 1 & Farmer & 40 & 40 \\
2 & Laborer & 22 & 22 \\
3 & Housewive & 17 & 17 \\
4 & Government & 6 & 6 \\
5 & employee & 4 & 4 \\
6 & Teacher & 3 & 3 \\
7 & Erader & 3 & 3 \\
8 & Fisherman & 2 & 2 \\
9 & Unemployed & 3 & 3 \\
\hline
\end{tabular}




\section{Income}

The general income on the community was at a range of IDR $1,000,000,-$ to $3,000,000$,- at the percentage of $41 \%$. The dominated income was IDR 2,000,000,-. Housewives were categorized as residents with no income and can be involved in forest restoration as workers.

Table 6 The characteristic of the community in Lepan watershed based on income

\begin{tabular}{llcc}
\hline No & $\begin{array}{l}\text { Income } \\
\text { (IDR/month) }\end{array}$ & $\begin{array}{l}\text { Number } \\
\text { (person) }\end{array}$ & Percentage (\%) \\
\hline 1 & IDR 0,- & 18 & 18 \\
2 & IDR 1,000,000,- & 3 & 3 \\
3 & IDR 1,500,000,- & 7 & 7 \\
4 & IDR 2,000,000,- & 41 & 41 \\
5 & IDR 2,500,000,- & 16 & 16 \\
6 & IDR 3,000,000,- & 15 & 15 \\
\hline
\end{tabular}

\subsection{The Public Perception}

Public perception is needed to obtain an overview of the conditions that occur in the research area and conduct an assessment of the community's knowledge of restoration. Sociology's expert stated that perception is the process of evaluating a person or group of people towards an object, event, or stimulus by involving experiences related to that object, through a technical process and affection to form the object [8]. The mostly community disagree on the forest function restoration, indicated by the total score of 386. People feel worried and threatened not to be able to carry out agricultural and plantation activities. The public perceptions of restoring forest functions are presented in Table 7.

Table 7 The public perception of forest function restoration

\begin{tabular}{rccc}
\hline \multicolumn{1}{c}{ Question } & $\begin{array}{c}\text { Scale of } \\
\text { answer }\end{array}$ & Number & $\begin{array}{c}\text { Scale answer } \\
\text { x value }\end{array}$ \\
\hline If forest functions are restored & & & \\
a. Strongly agree & 5 & 0 & 0 \\
b. Agree & 4 & 4 & 8 \\
c. Doubtful & 3 & 5 & 14 \\
d. Disagree & 2 & 91 & 364 \\
e. Strongly disagree & 1 & 0 & 0 \\
\hline & Total & & \\
\hline
\end{tabular}


According to Table 8, total score of respondent's knowledge and restoration implementation is 277 . This means the community acknowledged of restoration activities and it will make easier to socialize if restoration was carried out.

Table 8 Knowledge about restoration activities

\begin{tabular}{lccc}
\hline \multicolumn{1}{c}{ Question } & $\begin{array}{c}\text { Scale of } \\
\text { answer }\end{array}$ & Number & $\begin{array}{c}\text { Scale answer } \\
\text { x value }\end{array}$ \\
\hline $\begin{array}{l}\text { Do you know about } \\
\text { forest restoration } \\
\text { activities? }\end{array}$ & & & \\
a. Know & 3 & 79 & 237 \\
b. Doubtful & 2 & 19 & 38 \\
c. Not know & 1 & 2 & 2 \\
\hline \multicolumn{2}{r}{ Total } & & 277 \\
\hline
\end{tabular}

Table 9 shows the information that there has never been restoration activity in the research location it was proved by the total score of 100 . Therefore, restoration activity involving the local community is important and necessary.

Table 9 The restoration activity implementation

\begin{tabular}{lccc}
\hline \multicolumn{1}{c}{ Question } & $\begin{array}{c}\text { Scale of } \\
\text { answer }\end{array}$ & Number & $\begin{array}{c}\text { Scale } \\
\text { answer } \\
\text { x value }\end{array}$ \\
\hline $\begin{array}{l}\text { Have forest restoration activities been carried out? } \\
\text { a. Ever }\end{array}$ & 3 & 0 & 0 \\
b. Doubtful & 2 & 0 & 0 \\
c. Never & 1 & 100 & 100 \\
\hline
\end{tabular}

Out of 100 respondents obtained a total score of 407 (category A). This means the community agrees to approve rehabilitation and restoration activities which will be carried out (Table 10).

Table 10 The perception of conducting forest restoration activities

\begin{tabular}{llll}
\hline Question & $\begin{array}{l}\text { Scale of } \\
\text { answer }\end{array}$ & Number & $\begin{array}{l}\text { Scale } \\
\text { answer } \\
\text { x value }\end{array}$ \\
\hline $\begin{array}{l}\text { What is your opinion if forest restoration activities } \\
\text { carried out in this location? }\end{array}$ & 5 & & \\
a. Strongly agree & 4 & 28 & 140 \\
b. Agree & 3 & 59 & 236 \\
c. Doubtful & 2 & 5 & 15 \\
d. Disagree & 1 & 8 & 16 \\
e. Strongly disagree & & 0 & 0 \\
\hline
\end{tabular}




\subsection{The Degree of Community Participation Possibility}

Community participation is one of the things that can help the success of restoration activities. Therefore, activities can run smoothly and get the result as expected. One of the principles that can be used in efforts to carry out restoration is by using the principle of community empowerment and institutional capacity and participatory approaches. This is in accordance with [3], who stated that the degree of possibility of community participation is an important factor in determining the success of forest landscape restoration.

\subsection{Degree of community participation possibility in restoration planning}

The distribution of the degree of community participation possibility in restoration activity planning is presented in Figure 1.

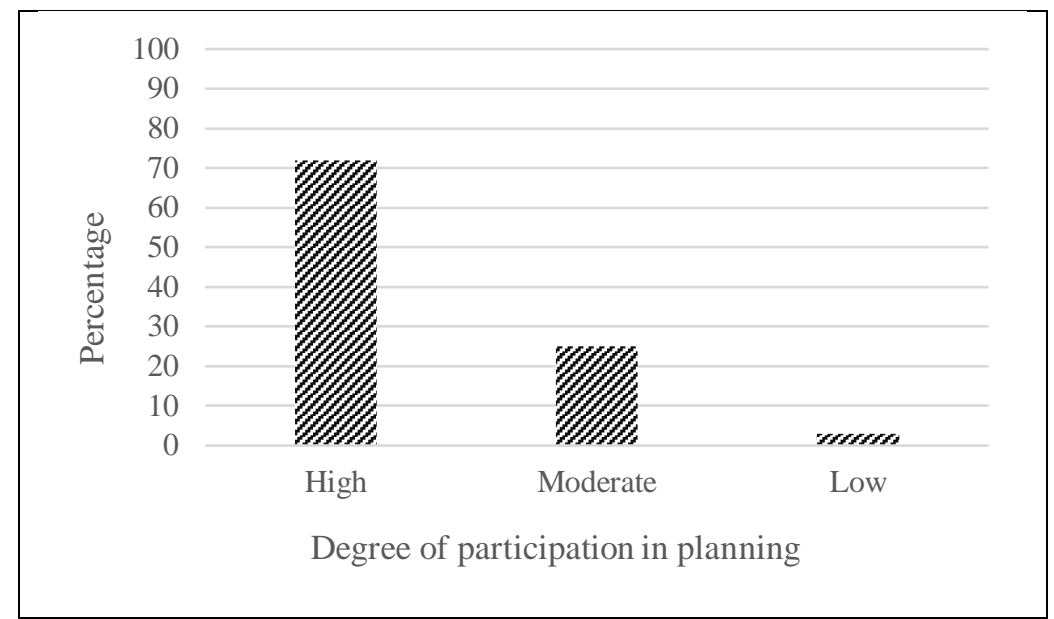

Figure 1 The distribution of community participation possibility in the activity of restoration planning

Community participation in restoration planning was categorized by high category, medium category, and low category with a proportion of $72 \%, 25 \%$, and $3 \%$, respectively. Communities on high category had a greater proportion of people compared to moderate or low category. This indicates the high passion and enthusiasm, showing the community is willing to be involved from the beginning of the planning.

\subsection{Degree of community participation possibility in the implementation of restoration}

The degree of community participation possibility in the implementation of restoration activities can be seen in Figure 2. 


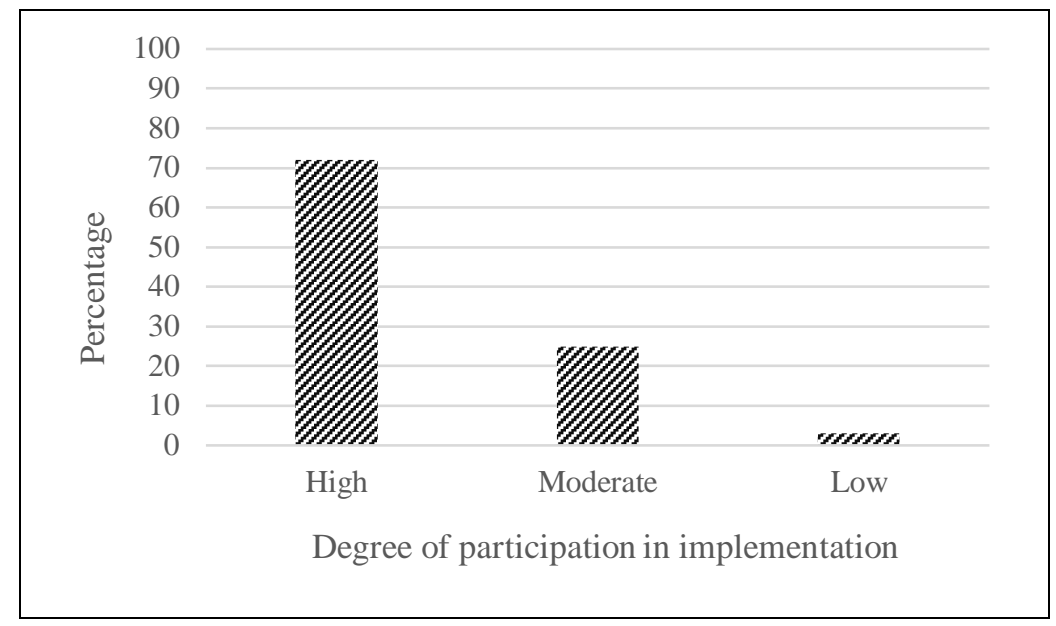

Figure 2 Degree of community participation possibility in the implementation of restoration activities

Figure 2 showed that the people who had a high degree of possible participation in the implementation of restoration activities (72\%) and those with a moderate and low category had a smaller proportion of $25 \%$ and $3 \%$. A high degree of participation is an important capital for the success of the restoration.

\subsection{Degree of community participation possibility in the maintenance of restoration}

The degree of community participation possibility in maintenance that included in the stages of restoration activities is shown in figure 3.

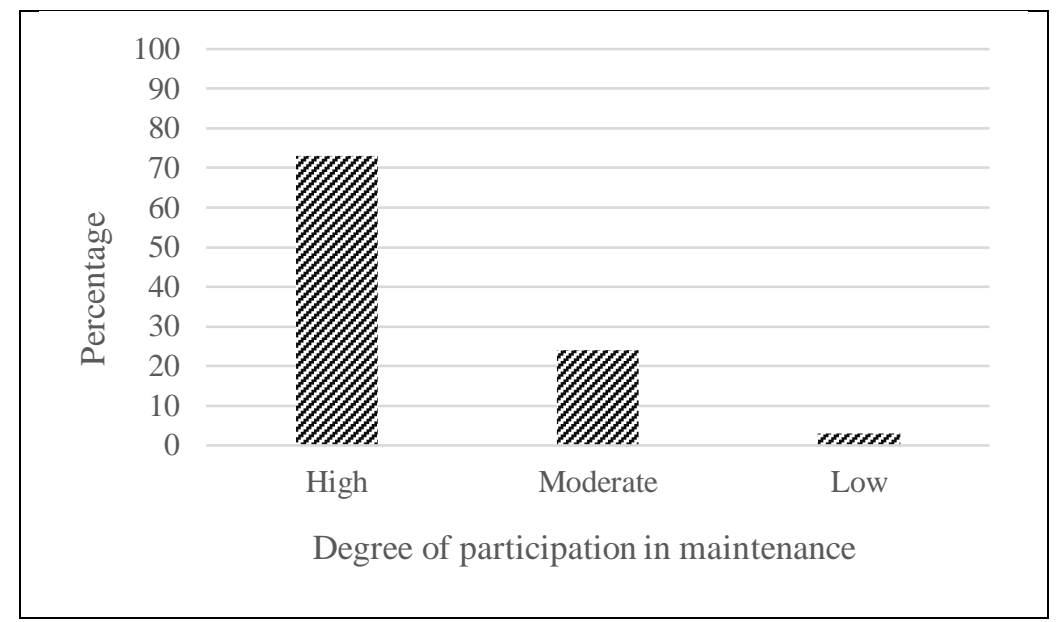

Figure 3 Degree of community participation possibility in the maintenance of restoration

As presented in Figure 3, the degree of community participation possibility on the maintenance of restoration is dominated by high category $(73 \%)$. Community participation with medium category and 
low category were $25 \%$ and $3 \%$, respectively. A high proportion of the community's role in maintenance will be able to support the successfulness of restoration.

\subsection{Degree of community participation possibility in the monitoring of restoration}

The degree of community participation possibility in the monitoring of restoration is graphically illustrated in Figure 4.

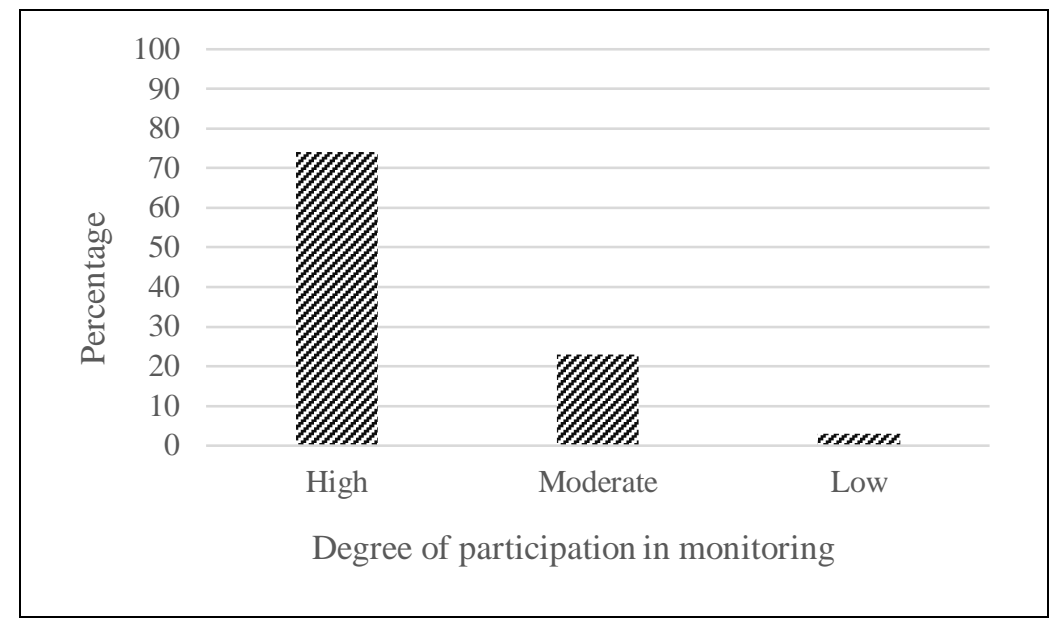

Figure 4 Degree of community participation possibility in the monitoring of restoration

Figure 4 showed that the community had a high possibility to participate in the monitoring of restoration activities $(74 \%)$. The possibility of people in the medium category and low category were $24 \%$ and $3 \%$, respectively.

\subsection{The average degree of community participation possibility}

The average degree of community participation possibility in all stages to be carried out in the restoration activities is presented in Figure 5. 


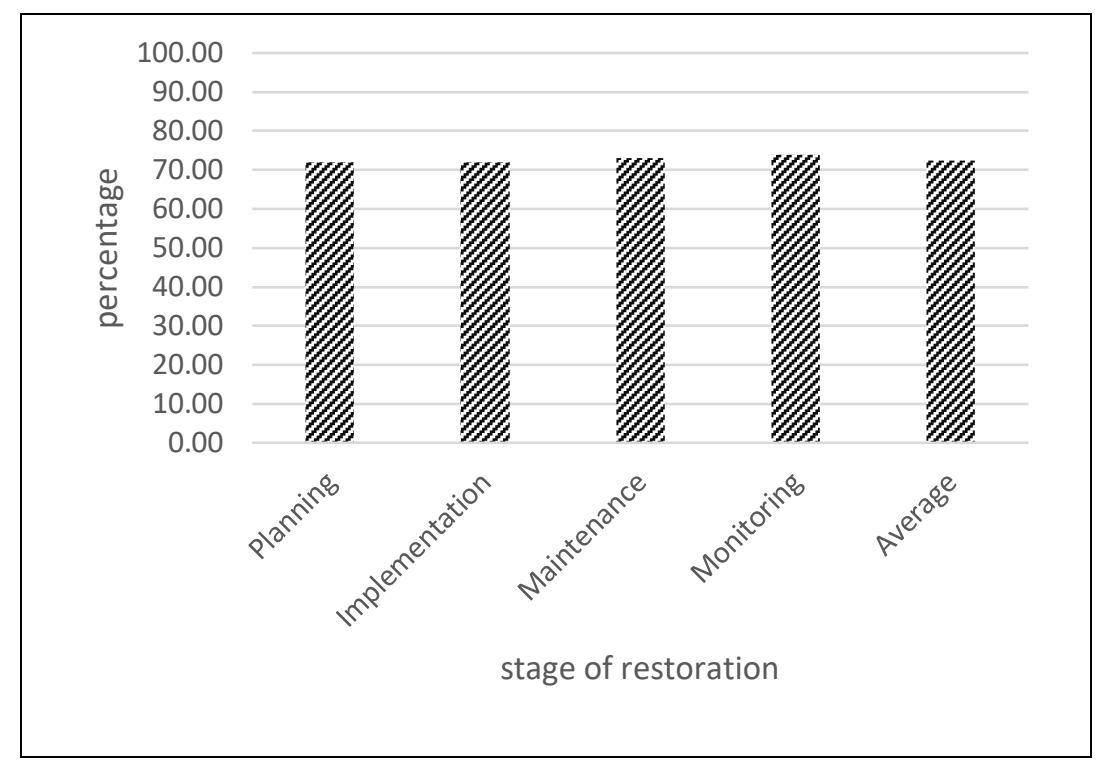

Figure 5 Degree of community participation possibility in restoration activities

According to Figure 5, the average degree of community participation possibility in the planning, implementation, maintenance, and monitoring of rehabilitation and restoration activities had a high category with a percentage of $72.75 \%$. The degree of participation possibility was obtained from the results of respondent's answers stating that they would participate in the activities. This shows that the community has a good understanding of the aims and objectives of the restoration activities.

\subsection{Determination of Plant Types}

Before planting, determining the type of plant for restoration is important. The plants chosen can be those proposed by the community, e.g. rare local plants which hard to find in the study area. The plants can also the ones recommended, the ones preferred and the ones most suitable to be planted according to the community. Vegetation analysis on both study area and natural forests on its surrounding were also influencing plant selection.

\section{A. Selection of plant types based on people's perceptions}

The selection of plants that suitable for restoration activities based on community opinion has a weight proportion of $40 \%$. In accordance with four reasons which to select tree species based on community perceptions, each reason has a proportion of $10 \%$. The types of plants suitable to use in planning restoration activities are presented in Table 11.

Table 11 Plant type based on community perception (20 top rankings) 


\begin{tabular}{clccccc}
\hline No. & $\begin{array}{l}\text { Plant Type } \\
\text { (local name) }\end{array}$ & 1 & 2 & 3 & 4 & $\begin{array}{c}\text { Total } \\
\text { Score x } \\
\text { Weight }\end{array}$ \\
\hline 1 & Rubber plant & 1.0 & 0.7 & 1.3 & 0.8 & 3.80 \\
2 & Rambutan & 1.0 & 1.1 & 1.1 & 0.9 & 3.65 \\
3 & Teak & 1.2 & 0.6 & 0.7 & 0.5 & 3.00 \\
4 & Durian & - & 1.3 & 1.2 & 1.0 & 3.00 \\
5 & Dammar & 0.6 & 1.0 & 1.0 & 0.6 & 2.90 \\
6 & Cempedak & 0.8 & 0.8 & 0.6 & 0.7 & 2.55 \\
7 & Orange & 0.1 & 1.2 & 0.8 & 0.8 & 2.50 \\
8 & Mahagony & - & 0.6 & 0.9 & 0.3 & 1.65 \\
9 & Black Dammar & 0.3 & 0.9 & 0.5 & - & 1.70 \\
10 & Merbau & 0.7 & 0.7 & - & 0.2 & 1.50 \\
11 & Meranti & 0.5 & 0.5 & 0.3 & - & 1.30 \\
12 & Jabon & 0.5 & 0.5 & - & - & 1.00 \\
13 & Mangosteen & 0.2 & 0.3 & 0.3 & - & 0.80 \\
14 & Stinkbean & - & 0.4 & 0.3 & - & 0.70 \\
15 & Cocoa & 0.2 & - & 0.4 & - & 0.60 \\
16 & Semantok & 0.4 & - & - & 0.3 & 0.55 \\
17 & Mango & 0.1 & 0.1 & 0.1 & 0.1 & 0.35 \\
18 & Sengon & 0.1 & 0.2 & - & - & 0.30 \\
19 & Rose apple & - & - & - & 0.2 & 0.10 \\
20 & Langsat & 0.1 & - & - & - & 0.10 \\
\hline
\end{tabular}

The most suitable species to plan on the restoration activity in Lepan watershed by community preference is rubber plant (Hevea brasiliensis) with score value 3.8. This was in accordance with [8], who stated that the rubber plant is a type of plantation that has high economic value. Rubber latex can be processed into rubber sheets, chunks, or crumbs (raw material for rubber industry). Rubberwood can be used to make furniture and other home appliances.

Ecologically, rubber plant easier adapted in environment. According to [9], the rubber plant is very prospective to be developed in the watershed area due to its excellent adaptability to various agroclimatic conditions.

\section{B. Plant type based on analysis of vegetation in natural forests}

Plant species selection based on natural forest vegetation analysis is one of a necessary step to be done to find out the types of plants found in natural forests around the planning area for restoration activities. Natural forest vegetation analysis provided information on tree species that can be a reference in determining the type of tree to be selected for planning restoration activities, according to the statement of Clewell et.al 2005 cited in [6]. Vegetation analysis was carried out to determine the composition of vegetation types and structures forest from the plant community. 
The analysis of natural forest vegetation was carried out on natural forests around the planning area for restoration activities. The valuation of plant species derived from the analysis of natural forest vegetation has a percentage of $60 \%$. The types of trees obtained are presented in Table 12.

Table 12 Plant type based on vegetation analysis in natural forest (20 top rankings)

\begin{tabular}{llll}
\hline No & $\begin{array}{l}\text { Name of plants } \\
\text { (local name) }\end{array}$ & $\begin{array}{l}\text { INP } \\
(\%)\end{array}$ & $\begin{array}{l}\text { Total } \\
\text { Score } x \\
\text { Weight }\end{array}$ \\
\hline 1 & Bayur & 26 & 9.0 \\
2 & Meranti & 20 & 8.4 \\
3 & Benoang & 18 & 7.8 \\
4 & Matoa & 14 & 7.2 \\
5 & Marak & 13 & 6.6 \\
6 & Jengkol & 11 & 6.0 \\
7 & Pulai & 10 & 5.4 \\
8 & Durian & 10 & 5.4 \\
9 & Meranti Batu & 9 & 4.8 \\
10 & Gusi Biang & 9 & 4.8 \\
11 & Gara Tar-Tar & 9 & 4.8 \\
12 & Meranti Gembung & 9 & 4.8 \\
13 & Rubber plant & 9 & 4.8 \\
14 & Capet & 8 & 4.2 \\
15 & Sukun & 8 & 4.2 \\
16 & Redas Malaysia & 8 & 4.2 \\
17 & Raja & 7 & 3.6 \\
18 & Karim Balang & 7 & 3.6 \\
19 & Kabu & 7 & 3.6 \\
20 & Ndeleng & 7 & 3.6 \\
\hline
\end{tabular}

According to Table 12, bayur (Pterosperium javanicum) has the highest Important Value Index (IVI) of $26 \%$ and has a total score of 24 . Bayur is a plant species of lowland forest which is good to cultivate and has health, economic, and ecological benefits.

The determination of plant species for Lepan watershed restoration activities planning was also considered the community perceptions and the results of natural forest vegetation analysis. Scoring analysis of the types of plants obtained from vegetation analysis generated plant species as presented in Table 13. 
Table 13 Most suitable plant types for restoration activities in Lepan watershed

\begin{tabular}{llc}
\hline No. & $\begin{array}{c}\text { Name of } \\
\text { plants (local } \\
\text { name) }\end{array}$ & Total Score x Weight \\
\hline 1 & Meranti & 9.7 \\
2 & Bayur & 9.0 \\
3 & Rubber plant & 8.6 \\
4 & Durian & 8.4 \\
5 & Benoang & 7.8 \\
6 & Matoa & 7.2 \\
7 & Marak & 6.6 \\
8 & Jengkol & 6.0 \\
9 & Pulai & 5.4 \\
10 & Meranti Batu & 4.8 \\
\hline
\end{tabular}

Table 13 shows the type of plants that have the highest rank 10 out of 56 plant species based on community perception and analysis of natural forest vegetation. These plants were eligible because easily found in natural forests around the location of planning for restoration activities. According to [6] who stated that the principle of determination was to choose the type of plant that was widely available at the natural forest ecosystem near the restoration site.

The said species were lowland forest vegetation. According to [10] who expressed that bayur, meranti, durian, meranti batu, and marak were lowland forest species. Benoang is also lowland rainforest species [11]. According to [12], jengkol is able to adapted well and able to grow at various heights: low and high plains, but the perfect quality of fruit pods and seeds obtained from the lowlands. According to [13], the rubber plant basically grows optimally in the lowlands. Matoa is a typical type of lowland rainforest (Westphal and Jansen (1989) in [13]. According to [15], pulai grows in lowland and mountainous forests and also found in secondary forests. This was in accordance with the conditions of the Lepan watershed which was at the altitude of 300-700 m above sea level. Lowland ecosystems are located at the altitude of $0-1,000 \mathrm{~m}$ above sea level.

\section{Conclusion}

1.The degree of community participation possibility in forest landscape rehabilitation and restoration activities in Lepan watershed was in high category with an average value of $74.25 \%$.

2. The types of plants that suitable for Lepan watershed restoration were meranti (Shorea sp), bayur (Pterosperium javanicum), rubber plant (Hevea brasiliensis), durian (Durio zibethinus), benoang (Octomeles sumatrana), matoa (Pometia pinnata), marak (Macaranga indica), 
jengkol (Pithecellobum jiringa), pulai (Alstonia scholaris), and meranti batu (Shorea parvifolia).

\section{Acknowledgment}

Authors would like to thank the University of Sumatera Utara, Ministry of Research and Higher

Education, for supporting us in research grant trough PUPT schema year 2016.

\section{REFERENCES}

[1] FWI/GFW, State of Indonesian Forests, Forest Watch Indonesia and Washington D.C. Global Forest Watch, Indonesia, 2001.

[2] W. C. Meliala, "Vegetation Density Analysis in the Land Cover class in the Lepan River Basin," M.S Thesis, University of Sumatera Utara, 2016.

[3] Samsuri, "Spatial Model Index for Restoration of Degraded Tropical Forest Landscapes in the Batang Toru Watershed, North Sumatra," Dr. Dissertation, Bogor Agricultural Institute, Bogor, 2014.

[4] A. Sudomo, "Research on the Level of Community Participation in the Implementation of Forest and Land Rehabilitation Activities (Case Study in Cisaga Village, Cisaga District, Ciamis District, West Java Province)," in Proceedings of SNaPP2011 Science Technology [Online]. Available: proceeding.unisba.ac.id. [Accessed: July 21, 2017, 11.01 WIB. 2011].

[5] A. Salim, C. Carol J. Pierce, In: M. Cynthia. and K. Ani and D.T. Meiske (Ed.), Guide to Score and Analyze the Human Welfare, Center for International Forestry Research (CIFOR), Bogor, 1999.

[6] P. Hadisiswoyo, S. Masrizal, A. Rio, A. Ahmad, and Wagiman, Field Guide to Indonesian Tropical Forest Ecosystem Restoration, YOSL-OIC and TFCA Sumatera, Jakarta, 2014.

[7] D Mahmud, Psikologi Pendidikan, Departemen Pendidikan dan Kebudayaan, Jakarta, 1989

[8] J.H. Purwanta, Kiswanto, and Slameto, Rubber Cultivation Technology, Institute for Agricultural Technology Studies, Lampung, 2008.

[9] I. Boerhendhy and S.A. Dwi, Prospects for Rubber Development in Watershed Areas, Sembawa Research Center, Rubber Research Center, Palembang, 2013.

[10] I. Heriansyah, S. Adi, and S. Atok, Guide to Gunung Leuser National Park Ecosystem Restoration, UNESCO Jakarta Office, Bogor, 2014.

[11] R.K. Adhi, "Guide of Binuang Plants," in Center for Binuang Agricultural Training. Available: www.bbpp-binuang.info. [Accessed: August 14, 2017 09.52 WIB. 2017].

[12] Y. Maxiselly and U. Debby, Jengkol Plant Exploration at Home Garden in Ciamis Regency, West Java, Departement of corp science Padjajaran University, Bandung, 2014.

[13] C. Anwar, Rubber Cultivation, Rubber Research Center, Field, 2001.

[14] H.L. Wambarau, "Morphological Characterization and Isozyme of Matoa (Pometia pinnata Forst.)," M.S Thesis, Bogor Agricultural Institute, Bogor, 2011.

[15] T.C. Whitemore, Tree Flora of Malaya: A Manual for Foresters, vol. 2 Longman, Malaysia, 1973. 